\title{
Warm blood versus St. Thomas cardioplegia for myocardial protection in patients undergoing coronary artery bypass grafting
} \author{
Antonio Pellegrino ${ }^{1}$, Dionisio F. Colella ${ }^{2}$, Dario Buioni ${ }^{1}$, Emanuele Tedone ${ }^{3}$, Giovanni Ruvolo ${ }^{1}$ \\ ${ }^{1}$ Cardiac Surgery Division, Tor Vergata University Hospital, Rome, Italy \\ ${ }^{2}$ Cardiac Anesthesiology Division, Tor Vergata University Hospital, Rome, Italy \\ ${ }^{3}$ Cardiovascular Perfusion Service, Tor Vergata University Hospital, Rome, Italy
}

Paolo Nardi ${ }^{1}$, Calogera Pisano ${ }^{1}$, Sabrina M. Ferrante ${ }^{1}$, Fabio Bertoldo ${ }^{1}$, Antonio Scafuri ${ }^{1}$, Carlo Bassano $^{1}$,

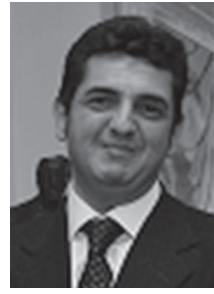

Kardiochir Torakochir Pol 2019; 16 (4): 147-154

\section{Abstract}

Aim: We retrospectively analyzed early results of coronary artery bypass grafting (CABG) surgery using antegrade intermittent warm blood or St. Thomas cold crystalloid cardioplegia. Material and methods: From January 2015 to May 2018, in 556 patients undergoing isolated CABG, cardiac arrest was obtained using warm blood (WB group, $n=402$ ) or St. Thomas cardioplegia (ST group, $n=154$ ). Myocardial enzymes' release was calculated at the end of CABG (time 0), 24, and 48 hours postoperatively.

Results: In-hospital mortality was $1.74 \%$ in the WB group, $0.65 \%$ in the ST group. As compared with the WB group, in the ST group the number of distal coronary artery anastomoses per patient was significantly higher $(2.9 \pm 0.9$ vs. $2.6 \pm 0.8)$ $(p=0.003)$, despite a similar required number of cardioplegia doses per patient $(2.2 \pm 0.9$ vs. $2.3 \pm 0.9)$. The incidence of perioperative myocardial infarction, low cardiac output syndrome, myocardial enzymes release, rate of CK-MB/CK ratio > 10\% was similar. As compared with the WB group, in the ST group the proportion of patients with $\mathrm{CK}-\mathrm{MB} / \mathrm{CK}$ ratio > $5 \%$ was lower at each time point of evaluation, with a significant difference at time $0(30.5 \%$ vs. $48 \%)(p=0.0005)$, whereas the need for blood transfusion per patient was higher ( $1.3 \pm 2.0 \mathrm{vs}$. $0.54 \pm 1.3)$ ( $p<0.0001)$. Within the WB group, the rate of CK-MB/CK ratio $>5 \%$ was significantly reduced when dose administration was repeated within 18 minutes compared to $20-25$ minutes (36\% vs. $59 \%)(p<0.0001)$. Duration of the extracorporeal circulation and of the aortic cross-clamping, and the mean number of coronary bypasses were not identified as risk factors either for the CK-MB/CK ratio greater than $10 \%$ or greater than $5 \%$. Conclusions: Based on a single-center experience, both types of cardioplegia are associated with equivalent clinical results. St. Thomas cardioplegia, despite the greater number of grafts per patient and therefore greater extracorporeal circulation and aortic cross-clamping times, and greater postoperative need for blood transfusion, appears to be associated with
\end{abstract}

\section{Streszczenie}

Cel: Przeprowadzono retrospektywną analizę wczesnych wyników operacji pomostowania tętnic wieńcowych (CABG) przy zastosowaniu podawanej do aorty (antegrade) ciepłej kardiopleginy krwistej lub zimnej kardiopleginy krystalicznej St. Thomas. Materiat i metody: Od stycznia 2015 do maja 2018 r. tącznie u 556 pacjentów poddawanych izolowanemu CABG uzyskano czasowe zatrzymanie akcji serca poprzez podawanie ciepłej kardiopleginy krwistej (grupa WB, $n=402$ ) lub kardiopleginy St. Thomas (grupa ST, $n=154$ ). Uwalnianie enzymów sercowych oznaczano pod koniec CABG (punkt czasowy 0), a także po upływie 24 i 48 godzin od operacji.

Wyniki: Śmiertelność szpitalna wyniosła 1,74\% w grupie WB i 0,65\% w grupie ST. W porównaniu z grupą WB w grupie ST liczba zespoleń dystalnych tętnic wieńcowych przypadających na pacjenta była istotnie wyższa $(2,9 \pm 0,9$ vs $2,6 \pm 0,8)$ $(p=0,003)$ pomimo zbliżonej liczby niezbędnych dawek kardiopleginy przypadających na pacjenta $(2,2 \pm 0,9$ vs 2,3 $\pm 0,9)$. Występowanie okołooperacyjnego zawału mięśnia sercowego i zespołu małego rzutu serca, a także uwalnianie enzymów sercowych i wartość stosunku CK-MB/CK > 10\% były zbliżone. W porównaniu z grupą WB $w$ grupie ST odsetek pacjentów z CK-MB/CK > 5\% był niższy w każdym punkcie czasowym oceny, z istotną różnicą w punkcie czasowym 0 (30,5\% vs 48\%) $(p=0,0005)$, natomiast potrzeba przetoczenia krwi na pacjenta była wyższa $(1,3 \pm 2,0$ vs $0,54 \pm 1,3)(p<0,0001)$. W grupie WB wartość stosunku CK-MB/CK > 5\% stwierdzano istotnie rzadziej, gdy kolejne dawki podawano w odstępie 18 minut w porównaniu z odstępem $20-25$ minut ( $36 \%$ vs $59 \%$ ) ( $p<0,0001)$. Nie wykazano, aby czas trwania krążenia pozaustrojowego i stosowania zacisku krzyżowego aorty oraz średnia liczba pomostów wieńcowych stanowiły czynniki ryzyka ani dla stosunku CK-MB/CK > 10\%, ani > 5\%.

Wnioski: Na podstawie doświadczeń jednego ośrodka należy stwierdzić, że oba rodzaje kardiopleginy umożliwiają uzyskiwanie równoważnych wyników klinicznych. Wydaje się, że

Address for correspondence: Calogera Pisano MD, PhD, Tor Vergata University Hospital, Viale Oxford 81, 00133-Rome, Italy, phone: +39(06)20903536, fax: +39(06)20903538, e-mail: lindapisano82@gmail.com

Received: 6.07.2019, accepted: 29.09.2019. 
a lower rate of CK-MB ratio > 5\%. Warm blood cardioplegia allows better protection when administered in an 18-minute re-dosing interval.

Key words: cardioplegia, coronary artery bypass, myocardial infarction.

\section{Introduction}

Cardioplegia represents the most important strategy aimed at protecting myocardial function during cardiac surgery and facilitating surgical procedures by providing a quiet and bloodless operative field.

Cardioplegic solution was introduced as an agent for hypothermic hyperkalemic arrest. Cold crystalloid cardioplegia associated with mild-to-moderate hypothermia has the advantage of decreasing the oxygen consumption and offers some degree of protection during periods of low flow or low perfusion pressure. Moreover, crystalloid cardioplegia gives a better view when performing distal coronary artery anastomoses.

The association of blood, for example in a $1: 4$ ratio, to cold cardioplegia was then found to be an important vehicle for delivery of potassium cardioplegia [1, 2].

Subsequently, warm blood cardioplegia has been proposed as a safe and reliable technique for myocardial protection, based on the rationale that blood, as opposed to crystalloid solution, can potentially improve postoperative cardiac outcomes, because it more closely approximates normal physiology, i.e. carrying oxygen to the myocardium or ensuring less hemodilution. Nevertheless, there is still a debate which is better cardioplegia for myocardial protection during cardiac surgical procedures [3-5].

Most recently, del Nido cardioplegia with a blood-crystalloid ratio of $1: 4$, mainly developed for use in pediatric patients to obtain better tolerability of immature myocardium to high levels of intracellular calcium, has been proposed as safe and effective also in adult cardiac surgery $[6,7]$.

\section{Aim}

The aim of this study was to retrospectively evaluate whether postoperative (PO) cardiac enzymatic levels and in-hospital outcomes, i.e., 30-day mortality and complications, in patients undergoing isolated coronary artery bypass grafting (CABG) were differently affected by using intermittent antegrade warm blood cardioplegia or cold crystalloid St. Thomas cardioplegia.

\section{Material and methods}

From January 2015 to May 2018 at the Cardiac Surgery Unit of the Tor Vergata University Hospital of Rome 556 kardioplegina St. Thomas - pomimo większej liczby pomostów przypadających na pacjenta, wydłużonego czasu krążenia pozaustrojowego i stosowania zacisku krzyżowego aorty, a także zwiększonego zapotrzebowania na pooperacyjne przetaczanie krwi - wiąże się z rzadszym występowaniem CK-MB o wartościach > 5\%. Ciepła kardioplegina krwista zapewnia lepszą ochronę, gdy jest podawana z zachowaniem 18-minutowego odstępu pomiędzy kolejnymi dawkami.

Słowa kluczowe: kardioplegia, pomostowanie tętnic wieńcowych, zawał mięśnia sercowego.

patients (mean age of $66.5 \pm 9.2$ years) underwent isolated CABG by means of cardiopulmonary bypass and cardioplegia-induced arrest. Cardiac arrest was obtained using warm blood cardioplegia (WB group, $n=402$ ) or cold crystalloid St. Thomas cardioplegic solution (ST group, $n=154$ ) on the basis of surgeons' choice and experience. These two groups of patients represented the object of the present study.

All patients underwent preoperatively trans-thoracic echocardiography and cardiac catheterization with selective coronary angiography, and postoperatively trans-thoracic echocardiography on the $3-4^{\text {th }}$ postoperative day. Patients operated on in emergency for acute evolving myocardial infarction, beating heart, or needing a redo operation or coronary endarterectomy were excluded.

The study was approved by the Local Institutional Review Board, which waived the need for patient consent. This study was designed as a retrospective one.

\section{Data collection}

In all patients levels of PO serum myocardial enzymes, i.e., total creatine kinase (CK), creatine kinase MB (CK-MB), aspartate transaminase (AST), cardiac troponin I (cTnl), were evaluated at the end of the operation (time 0 , i.e., at admission to intensive care unit), 24 and 48 hours $\mathrm{PO}$ after CABG. The values of CK-MB/CK ratio greater than (>) $10 \%$ and greater than ( $>$ ) $5 \%$ were also measured at the same times. The $10 \%$ and $5 \%$ threshold respectively of CK-MB to the total CK was calculated to evaluate the postoperative myocardial damage at different severity levels.

Perioperative myocardial infarction was defined as an increase of PO cTnl levels above $10 \mathrm{ng} / \mathrm{ml}$ associated with an increase of serum CK-MB enzyme more than $10 \%$ of the total CK enzyme, and the onset of ECG anomalies.

Complete revascularization was defined when each of three major vascular territories subtended by a significant coronary artery stenosis was grafted, or when the coronary bypass could not be performed because the coronary tributary vessel was of a caliber less than $1 \mathrm{~mm}$ and was considered prognostically irrelevant.

Postoperative low output cardiac syndrome was defined by a cardiac index value less than $2.0 \mathrm{l} / \mathrm{min} / \mathrm{m}^{2}$, requiring inotropic support for a period greater than 24 hours or the use of an intra-aortic balloon pump. 
Major non-cardiac complications were also analyzed: a pulmonary complication was defined as an episode of primary respiratory failure requiring mechanical ventilation for more than 48 hours, re-intubation, or intermittent application of non-invasive positive-pressure ventilation; permanent neurological complication due to focal or general cerebral lesion was defined as a stroke; transient ischemic attack was defined when neurological symptoms lasted less than 24 hours before disappearing; acute kidney injury was defined as a two-fold increase of preoperative serum creatinine level or oliguria requiring need of continuous veno-venous hemo-filtration.

The need for PO red blood cell unit transfusions and intensive care unit stay were also analyzed.

Operative mortality included death for any in-hospital causes after operation, at any time or within 30 days after discharge.

\section{Surgical procedure}

CABG was carried out in all patients by complete longitudinal sternotomy, normothermic or in mild hypothermia cardiopulmonary bypass with right atrial cannulation and arterial cannulation in the ascending aorta, and aortic cross-clamping.

Type of cardioplegia was given in accordance with the surgeons' choice and experience: two surgeons (GR, FB) used warm blood cardioplegia from January 2015 to April 2016, and subsequently crystalloid cold St. Thomas cardioplegic solution; all the other surgeons employed warm blood cardioplegia throughout the study period. Among the latter surgeons, one surgeon (PN) administered cardioplegia below or within 18 (15-18) minutes of the previous administration, while the others did so every $20-25 \mathrm{mi}$ nutes.

In the ST group intermittent antegrade cold $\left(4^{\circ} \mathrm{C}\right)$ crystalloid cardioplegia $(10 \mathrm{ml} / \mathrm{kg}$ the first dose, followed by doses of $5 \mathrm{ml} / \mathrm{kg}$ ) was administered every 25-30 minutes. In the WB group intermittent antegrade warm $\left(33-35^{\circ} \mathrm{C}\right)$ blood cardioplegia was administered as a first dose of $600 \mathrm{ml}$, followed by doses of $400 \mathrm{ml}$, each in 2 minutes; moreover, 20-40 ml of warm blood cardioplegia was injected into saphenous vein grafts at the end of each distal anastomosis.

Coronary artery bypass surgery was performed using in most cases the left internal mammary artery as a graft to the left anterior descending artery in association with saphenous vein, single or in Y-graft composition, as a graft to the right coronary artery and/or to the left circumflex artery branches.

\section{Statistical analysis}

Statistical analysis was performed with Stat View 4.5 (SAS Institute Inc, Abacus Concepts, Berkeley, CA). All continuous values were expressed as mean plus or minus 1 standard deviation of the mean. Student's $t$ test for continuous data and the $\chi^{2}$ or Fisher's exact test for categorical data were used.
The following preoperative and intra-operative variables were analyzed as risk factors for increased level of cardiac enzymes, i.e., CK-MB/total-CK ratios: age, gender, EuroSCORE II Risk Stratification System, presence of recent myocardial infarction, smoking habit, co-morbidity (arterial hypertension, diabetes mellitus, chronic renal dysfunction, chronic obstructive pulmonary disease, dyslipidemia, peripheral arteriopathy, obesity, poor mobility), NYHA (New York Heart Association) class, Canadian Cardiovascular Society (CCS) 4 grade of angina, need for urgent or elective operation, preoperative left ventricular ejection fraction, number of diseased coronary artery vessels, number of grafts per patient, cardiopulmonary bypass and aortic cross-clamp times, types and times of cardioplegia delivered. The ANOVA test was used to calculate repeated measures of myocardial enzymes levels at time 0, PO 24 and 48 hours.

Logistic Regression analysis was performed to identify independent risk factors of CK-MB/total-CK ratios greater than $5 \%$ and $10 \%$. All $p$ values less than 0.05 were considered statistically significant.

\section{Results}

Preoperative characteristics are presented in Table I. Both groups were similar for most of the preoperative characteristics, except for a greater incidence of arterial hypertension in the WB group $(p=0.015)$, and a greater incidence of poor mobility in the ST group $(p<0.0001)$. Intraoperative data are summarized in Table II. Aortic crossclamp and cardiopulmonary bypass times were longer in the ST group. Although the mean number of cardioplegia doses per patient was similar in both groups ( $2.2 \pm 0.9$ vs. $2.3 \pm 0.9 ; p=$ not significant), the mean number of distal coronary artery anastomoses per patient was higher in the ST group ( $2.9 \pm 0.9$ vs. $2.6 \pm 0.8)(p=0.003)$. However, complete revascularization was achieved in all patients of both groups.

Operative mortality was $1.4 \%(n=8) ; 1.74 \%$ in the WB group, and $0.64 \%$ in the ST group ( $p=$ not significant). Five deaths were due to cardiac causes ( 2 for low output cardiac syndrome, 2 for myocardial infarction, 1 for sudden death), 1 death due to mesenteric ischemia, 2 deaths due to septic shock associated with multi-organ failure.

The incidence of perioperative myocardial infarction, low cardiac output syndrome, stroke, acute kidney injury, pulmonary complications, re-exploration for bleeding, atrioventricular blocks requiring need for pacemaker implantation, onset of paroxysmal atrial fibrillation and postoperative intensive care unit stay were similar in both groups. The postoperative mean value of left ventricular ejection fraction was similar in both groups. In contrast, the mean number of red blood cell units per patient transfused was significantly higher in the ST group $(p<0.0001)$.

\section{Cardiac enzyme measurements}

Serum levels of myocardial enzymes, i.e., CK-MB, total $\mathrm{CK}, \mathrm{CK}-\mathrm{MB} / \mathrm{CK}$ ratio in percent value, ALT, AST, and cardiac 
Table I. Preoperative characteristics

\begin{tabular}{|c|c|c|c|}
\hline Variable & $\begin{array}{l}\text { WB group } \\
(n=402)\end{array}$ & $\begin{array}{l}\text { ST group } \\
(n=154)\end{array}$ & $P$-value \\
\hline Age [years] & $72.6 \pm 9.8$ & $65.8 \pm 9.3$ & 0.078 \\
\hline EuroSCORE II (\%) & $2.5 \pm 2.0$ & $2.4 \pm 2.17$ & 0.585 \\
\hline Sex, female & $74(18.4 \%)$ & $21(13.6 \%)$ & 0.289 \\
\hline Body surface area $\left[\mathrm{m}^{2}\right]$ & $1.8 \pm 0.3$ & $1.8 \pm 0.4$ & 0.933 \\
\hline Body mass index $\left[\mathrm{kg} / \mathrm{m}^{2}\right]$ & $27.7 \pm 4.6$ & $26.9 \pm 4.4$ & 0.362 \\
\hline NYHA class, mean \pm SD & $1.8 \pm 0.8$ & $1.9 \pm 0.8$ & 0.468 \\
\hline Obesity & 76 (18.9\%) & $23(14.9 \%)$ & 0.267 \\
\hline Hypertension & 337 (83.8\%) & $115(74.7 \%)$ & 0.015 \\
\hline Diabetes on oral therapy & $73(18.2 \%)$ & $29(18.8 \%)$ & 0.854 \\
\hline Diabetes on insulin therapy & $86(21.4 \%)$ & $31(20.1 \%)$ & 0.816 \\
\hline Dyslipidemia & 225 (55.9\%) & $80(51.9 \%)$ & 0.394 \\
\hline Smokers & $192(47.8 \%)$ & $70(45.5 \%)$ & 0.608 \\
\hline Chronic lung disease & $20(5.0 \%)$ & $10(6.4 \%)$ & 0.486 \\
\hline Extracardiac arteriopathy & 48 (11.9\%) & $20(12.9 \%)$ & 0.737 \\
\hline Poor mobility & $3(0.75 \%)$ & $12(7.94 \%)$ & $<0.0001$ \\
\hline Creatinine $[\mathrm{mg} / \mathrm{dl}]$ & $1.37 \pm 2.6$ & $1.27 \pm 1.0$ & 0.641 \\
\hline $\begin{array}{l}\text { Creatinine clearance } \\
{[\mathrm{ml} / \mathrm{min}]}\end{array}$ & $77.6 \pm 28.0$ & $82.7 \pm 38.8$ & 0.161 \\
\hline Renal impairment on dialysis & $6(1.49 \%)$ & $4(2.59 \%)$ & 0.398 \\
\hline Hemoglobin [g/dl] & $12.4 \pm 1.6$ & $11.9 \pm 1.5$ & 0.241 \\
\hline CCS 4 class & $181(45 \%)$ & $58(37.7 \%)$ & 0.252 \\
\hline Urgent surgery & $315(78.4 \%)$ & $117(76 \%)$ & 0.693 \\
\hline Recent myocardial infarction & $128(31.8 \%)$ & $58(37.7 \%)$ & 0.196 \\
\hline $\begin{array}{l}\text { Cardiac troponin I (cTnl) } \\
{[\mathrm{ng} / \mathrm{ml}]}\end{array}$ & $0.02 \pm 0.06$ & $0.02 \pm 0.05$ & 0.796 \\
\hline CK-MB [ng/ml] & $1.63 \pm 1.43$ & $2.05 \pm 2.45$ & 0.051 \\
\hline $\mathrm{CK}[\mathrm{U} / \mathrm{I}]$ & $88.6 \pm 59.9$ & $103 \pm 72.9$ & 0.069 \\
\hline AST [U/I] & $22.6 \pm 14.9$ & $23.6 \pm 14.5$ & 0.513 \\
\hline ALT [U/l] & $32.4 \pm 20.7$ & $35.8 \pm 27.1$ & 0.153 \\
\hline LVEF (\%) & $51.8 .0 \pm 7.9$ & $51.7 \pm 7.9$ & 0.907 \\
\hline $\begin{array}{l}\text { Pulmonary arterial pressure } \\
{[\mathrm{mm} \mathrm{Hg}]}\end{array}$ & $25.1 \pm 4.8$ & $23.6 \pm 5.2$ & 0.002 \\
\hline \multicolumn{4}{|l|}{ No. diseased coronary vessels: } \\
\hline One & $21(5.2 \%)$ & $6(3.9 \%)$ & 0.964 \\
\hline Two & $91(22.6 \%)$ & $30(19.4 \%)$ & 0.619 \\
\hline Three & $290(72.1 \%)$ & $118(76.6 \%)$ & 0.280 \\
\hline Left main stem disease & $129(32.1 \%)$ & $52(33.8 \%)$ & 0.706 \\
\hline
\end{tabular}

EuroSCORE - European System for Cardiac Operative Risk Evaluation,

ALT - alanine transaminase, AST - aspartate transaminase, CCS - Canadian Cardiovascular Society, LVEF - left ventricular ejection fraction, NYHA - New York Heart Association.

troponin I levels, at time 0 , and PO 24 and 48 hours after CABG, were substantially similar in both groups (Table III).

The incidence of $\mathrm{CK}-\mathrm{MB} / \mathrm{CK}$ ratio $>10 \%$ was similar during each time point of evaluation in both groups (Figure 1 ). The only independent predictor of CK-MB/CK ratio > 10\% was the preoperative CCS 4 grade of angina ( $p=0.015$; $\mathrm{HR}=4.13 ; 95 \% \mathrm{Cl}: 1.315-12.98)$.
Table II. Intraoperative and postoperative outcomes

\begin{tabular}{|c|c|c|c|}
\hline Variable & $\begin{array}{l}\text { WB group } \\
(n=402)\end{array}$ & $\begin{array}{l}\text { ST group } \\
(n=154)\end{array}$ & $P$-value \\
\hline CPB time [min] & $96.4 \pm 32.4$ & $104.9 \pm 38.3$ & 0.0089 \\
\hline Aortic cross-clamp time [min] & $56.3 \pm 21.3$ & $65.7 \pm 23.6$ & $<0.0001$ \\
\hline No. cardioplegia doses & $2.3 \pm 0.9$ & $2.2 \pm 0.9$ & 0.182 \\
\hline $\begin{array}{l}\text { No. coronary artery bypass } \\
\text { grafts }\end{array}$ & $2.6 \pm 0.8$ & $2.9 \pm 0.9$ & 0.0003 \\
\hline $\begin{array}{l}\text { Perioperative myocardial } \\
\text { infarction }\end{array}$ & $4(1.0 \%)$ & $2(1.3 \%)$ & 0.563 \\
\hline Low output cardiac syndrome & $7(1.7 \%)$ & $5(3.2 \%)$ & 0.326 \\
\hline $\begin{array}{l}\text { Inotropic drugs use } \\
>24 \text { hours }\end{array}$ & $12(3.0 \%)$ & $9(5.8 \%)$ & 0.130 \\
\hline Intra-aortic balloon pump & $2(0.5 \%)$ & $4(2.6 \%)$ & 0.046 \\
\hline Pulmonary complications & $10(2.5 \%)$ & $7(4.5 \%)$ & 0.222 \\
\hline Stroke & $4(1.0 \%)$ & 0 & 0.580 \\
\hline Creatinine time $0[\mathrm{mg} / \mathrm{dl}]$ & $0.47 \pm 0.2$ & $0.45 \pm 0.3$ & 0.587 \\
\hline Creatinine 24 hours [mg/dl] & $1.16 \pm 0.9$ & $1.22 \pm 1.1$ & 0.614 \\
\hline Creatinine 48 hours [mg/dl] & $1.06 \pm 0.9$ & $1.01 \pm 0.7$ & 0.592 \\
\hline $\begin{array}{l}\text { Creatinine clearance } \\
24 \text { hours [ml/min] }\end{array}$ & $80.9 \pm 34.7$ & $84.5 \pm 38.6$ & 0.393 \\
\hline $\begin{array}{l}\text { Creatinine clearance } \\
48 \text { hours [ml/min] }\end{array}$ & $91.0 \pm 40.3$ & $101.2 \pm 45.2$ & 0.041 \\
\hline $\begin{array}{l}\text { AKI requiring replacement } \\
\text { therapy }\end{array}$ & $2(0.5 \%)$ & 0 & 0.668 \\
\hline LVEF (\%) & $51.2 \pm 6.8$ & $52.0 \pm 6.9$ & 0.160 \\
\hline Paroxysmal atrial fibrillation & $130(32.3 \%)$ & $54(35.1 \%)$ & 0.571 \\
\hline Pacemaker implantation & $1(0.25 \%)$ & 0 & $>0.999$ \\
\hline Sternal wound dehiscence & $4(1.0 \%)$ & $3(1.9)$ & 0.389 \\
\hline Re-exploration for bleeding & $10(2.5 \%)$ & $2(1.3 \%)$ & 0.362 \\
\hline $\begin{array}{l}\text { Blood loss from chest drainage } \\
\text { tubes at } 24 \text { hours [ml] }\end{array}$ & $502 \pm 198$ & $480 \pm 218$ & 0.465 \\
\hline $\begin{array}{l}\text { No. (mean } \pm \mathrm{SD} \text { ) red blood } \\
\text { cells units transfused }\end{array}$ & $0.54 \pm 1.3$ & $1.31 \pm 2.0$ & $<0.0001$ \\
\hline ICU stay [days] & $3.8 \pm 6.0$ & $3.0 \pm 2.1$ & 0.148 \\
\hline Intraoperative mortality & $2(0.5 \%)$ & 0 & 0.668 \\
\hline 30-day mortality & $7(1.74 \%)$ & $1(0.64 \%)$ & 0.171 \\
\hline
\end{tabular}

AKI - acute kidney injury, ICU - intensive care unit, LVEF - left ventricular ejection fraction.

In contrast, a greater incidence of $\mathrm{CK}-\mathrm{MB} / \mathrm{CK}$ ratio $>5 \%$ was found in the WB group in comparison with the ST group, with a statistical level of significance at time 0 (Figure 2). An independent predictor of the CK-MB/CK ratio $>5 \%$ was the use of warm blood cardioplegia $(p=0.003$; $\mathrm{HR}=2.18$; 95\% Cl: 1.433-3.316).

However, when the delivery of warm blood cardioplegia was stratified according to the time of administration, i.e., within 18 minutes between one administration and the next, or 20-25 minutes, we found that the incidence of CK-MB/CK ratio > 5\% was significantly different, in favor of the 18-minute interval (Figure 3, Table IV). In fact, at time 0 the incidence of the CK-MB/CK ratio > 5\% was 36\% (74 patients out of 205) when blood cardioplegia was administered 
Table III. Serum levels of enzymes

\begin{tabular}{lccc} 
Parameter & $\begin{array}{c}\text { WB group } \\
(n=402)\end{array}$ & $\begin{array}{c}\text { ST group } \\
(n=154)\end{array}$ & $P$-value \\
\hline CK-MB time 0 [ng/ml] & 17.1 & 22.0 & 0.001 \\
\hline CK-MB 24 hours [ng/ml] & 24.2 & 18.2 & 0.066 \\
\hline CK-MB 48 hours [ng/ml] & 8.98 & 7.98 & 0.435 \\
\hline CK time 0 [U/l] & 403.5 & 555.1 & 0.001 \\
\hline CK 24 hours [U/l] & 621.5 & 764.2 & 0.013 \\
\hline CK 48 hours [U/l] & 605.2 & 676.6 & 0.367 \\
\hline CTnl time 0 [ng/ml]) & 3.45 & 4.22 & 0.115 \\
\hline CTnl 24 hours [ng/ml] & 5.34 & 6.09 & 0.418 \\
\hline CTnl 48 hours [ng/ml] & 4.06 & 4.15 & 0.922 \\
\hline CK-MB/CK ratio (mean v. \%) & 5.1 & 4.8 & 0.547 \\
time 0 & & & \\
\hline CK-MB/CK ratio (mean v. \%) & 4.8 & 3.3 & 0.558 \\
24 hours & & & \\
\hline CK-MB/CK ratio (mean v. \%) & 6.9 & 4.4 & 0.780 \\
48 hours & & & \\
\hline AST time 0 [U/l] & 51.8 & 61.3 & 0.342 \\
\hline AST 24 hours [U/l] & 54.7 & 63.6 & 0.328 \\
\hline AST 48 hours [U/l] & 45.9 & 118.4 & 0.080 \\
\hline ALT time 0 [U/l] & 38.5 & 39.9 & 0.798 \\
\hline ALT 24 hours [U/l] & 40.0 & 45.7 & 0.457 \\
\hline ALT 48 hours [U/l] & 35.4 & 128.1 & 0.534 \\
\hline & & & \\
\hline
\end{tabular}

Table IV. Independent predictors of CK-MB/total CK ratio greater than $5 \%$

\begin{tabular}{lccc} 
Variable & HR & $95 \% \mathrm{CI}$ & P-value \\
$\begin{array}{l}\text { Warm Blood Cardioplegia Group } \\
\text { (total patient population) versus }\end{array}$ & 2.18 & $1.433-3.316$ & 0.003 \\
$\begin{array}{l}\text { Cold Crystalloid Cardioplegia Group } \\
\text { Warm Blood Cardioplegia }\end{array}$ & 0.76 & $0.510-1.134$ & 0.179 \\
$\begin{array}{l}\text { Sub-Group (administered within } \\
18 \text { minutes) versus Cold Crystalloid } \\
\text { Cardioplegia Group }\end{array}$ & & & \\
\hline
\end{tabular}

within the 18-minute interval, and 59\% (115 patients out of 195) when it was administered in an interval of 20-25 minutes. In the logistic regression analysis, the administration of warm blood cardioplegia within 18 minutes was a protective factor against the CK-MB/CK ratio > 5\% (coefficient = $-0.274 ; \mathrm{HR}=0.76 ; 95 \% \mathrm{Cl}$ : 0.510-1.134) (Table IV). In contrast, in the univariate and the multivariable analyses the duration of the extracorporeal circulation, of the aortic cross-clamping times, and the mean number of coronary bypasses were not identified as risk factors either for the CK-MB/CK ratio greater than $10 \%$ or for the ratio greater than $5 \%$.

\section{Discussion}

The best method of myocardial protection during cardiac arrest is to cause the least possible damage to the heart

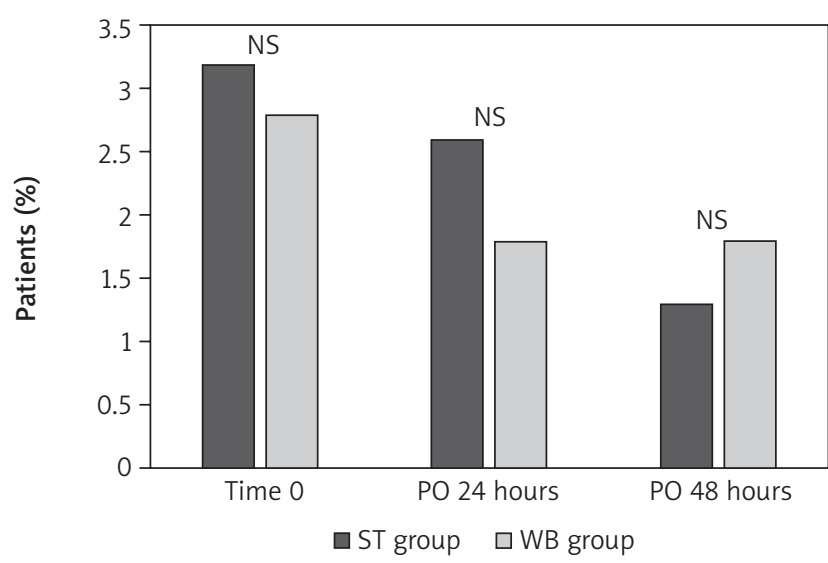

Figure 1. Postoperative rate of CK-MB/CK ratio > $10 \%$ in ST group and WB group

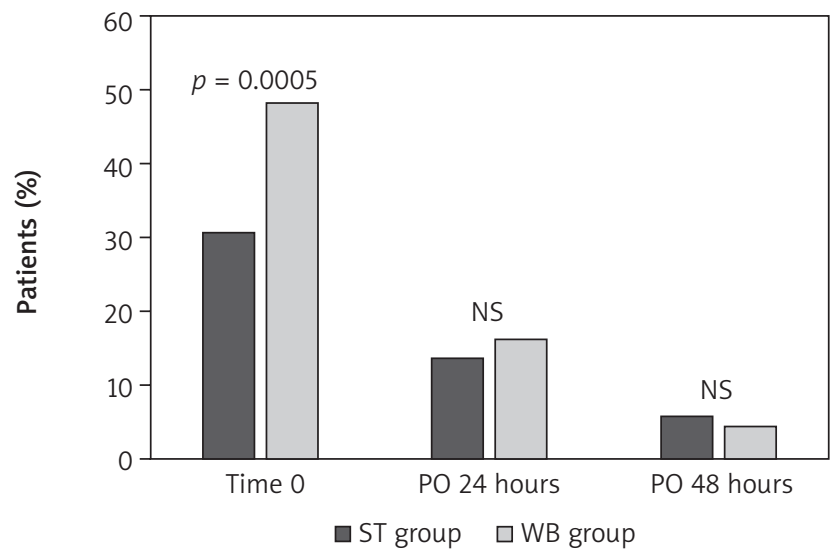

Figure 2. Postoperative rate of $\mathrm{CK}-\mathrm{MB} / \mathrm{CK}$ ratio $>5 \%$ in $\mathrm{ST}$ group and WB group

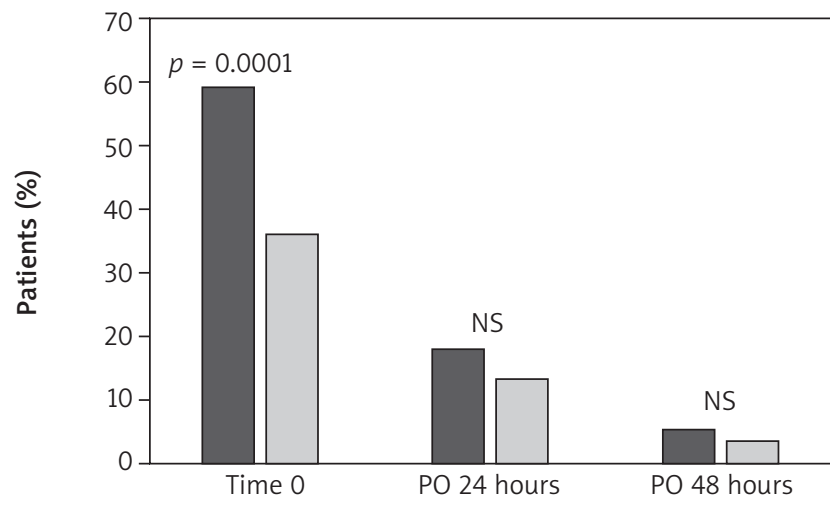

- WB group (cardioplegia administered every 20-25 minutes) $\square$ WB group (cardioplegia administered within 18 minutes)

Figure 3. Postoperative rate of CK-MB/CK ratio > 5\% in WB group according to administration in two different interval times

muscle, to better preserve ventricular contractile function, and not to cause perioperative myocardial infarction.

However, several questions remain open regarding the use of warm versus cold cardioplegia, blood versus crystalloid cardioplegia, antegrade versus retrograde delivery and intermittent versus continuous perfusion [8-10]. 
The debate over the optimal temperature of cardioplegia during cardiac surgery has been one of the most important aspects of myocardial protection. Early cardioplegic techniques used cold crystalloid solutions to initiate and maintain cardiac arrest during heart surgery, and it remained as a cornerstone of cardiac surgical practice since its introduction in the early 1950s. Although it could lower myocardial oxygen demand and consequently the risk of ischemic damage, cold cardioplegia might inhibit myocardial enzymes and it may result in a delay in metabolic and functional cardiac recovery after surgery. In the hope of maximizing intra-operative myocardial protection, warm blood cardioplegia was first introduced in the 1970s. Intermittent perfusions of warm blood cardioplegia were introduced in the 1980s and proved to provide satisfactory myocardial protection. Several randomized controlled trials have been conducted to compare warm cardioplegia with cold cardioplegia for myocardial protection, but the outcomes of these studies remained inconclusive [11-13].

Fan et al. [14], in a large meta-analysis identifying 41 randomized controlled trials including 5,897 patients, compared warm cardioplegia with cold cardioplegia, blood or crystalloid, showing that the risk of in-hospital death and myocardial infarction was similar.

Low output cardiac syndrome caused by myocardial damage from inadequate myocardial protection is a strong predictor of both perioperative and late death, and it could also prolong in-hospital stay and costs. The Warm Heart Trial Investigators [11] reported that a lower incidence of postoperative low output syndrome occurred in the warm cardioplegia group [14].

Partially similar results were reported by Guru et al. in another meta-analysis performed on 4,316 patients who underwent cardiac surgery procedures using blood (cold, tepid or warm) or cold crystalloid cardioplegia. Also in this meta-analysis CABG surgery was the procedure mostly performed. Blood cardioplegia provided superior myocardial protection as compared with crystalloid cardioplegia in terms of minor incidence of low output syndrome and reduced CK-MB release, but the incidence of death and myocardial infarction were found to be similar [15].

In two more recently published meta-analyses performed by Abah et al. [16], and by Zeng et al. [17], on 5,897 and 2,866 patients undergoing cardiac surgery, the conclusions were different: in the first one warm and cold cardioplegia resulted in similar short-term mortality and outcomes, while in the last one cold blood cardioplegia reduced the incidence of perioperative myocardial infarction in comparison with cold crystalloid cardioplegia. Fedosova et al. [18] in a study on 4,852 patients selected from Western Denmark Heart registry undergoing cardiac surgery and propensity-matched into crystalloid and blood cardioplegia administered every 20 minutes did not find clear evidence of superiority in terms of short-term mortality, myocardial infarction, stroke, or need for dialysis, but they found that in the presence of a longer aortic cross-clamp time or when prolonged postoperative ventilation was expected, blood cardioplegia may be preferable.
Kuhn et al. in a single-center study-selected population of patients undergoing isolated CABG $(n=950)$ showed that Buckberg cold blood cardioplegia and Calafiore warm blood cardioplegia offered comparable myocardial protection and similar outcomes, i.e., 30-day mortality and MACE [19].

Ulugol et al. [20] in a small sample of CABG patients receiving warm blood or cold crystalloid cardioplegia focused their attention on the postoperative cellular injury, and they concluded that both cardioplegic solutions created similar effects on glycocalyx integrity, but myocardial protection was better achieved with the use of warm blood cardioplegia.

De Jonge et al., in a study carried out on 7,138 CABG patients operated on in a 12-year period, reported that the use of blood cardioplegia in the multivariate analysis was associated with levels of CK-MB (cut-off $100 \mathrm{U} / \mathrm{l}$ ) significantly higher in comparison with the use of cold crystalloid cardioplegia; however, this difference did not determine different clinical results in the two groups of patients [21].

Also in order to assess what the most protective cardioplegia method for the myocardium may be in CABG surgery, the use of del Nido cardioplegia, which, as is known, is frequently used in pediatric surgery, has also been studied in adult patients.

Four recently published studies, one of which was a meta-analysis on several hundred patients, which compared the use of cardioplegia del Nido with the use of warm and cold blood cardioplegia, i.e. Buckberg, found no substantial differences in the short-term clinical results, although emphasizing that the use of cardioplegia del Nido was associated with a shorter duration of extracorporeal circulation and aortic cross-clamp time, as well as a lower tendency to the need for blood transfusion in the postoperative period. Therefore, all the authors concluded their studies by stating that del Nido cardioplegia can be considered as an effective method of myocardial protection also in adult cardiac surgery [22-25].

Sanetra et al., making a more focused analysis on more recent publications on the del Nido cardioplegia, highlight how the use of this cardioplegia also in adult surgery seems to be associated with a lower incidence of postoperative ventricular arrhythmias, underlining, however, the need for large randomized trials to evaluate its possible superiority in comparison with other cardioplegic solutions [26].

Analysis of our results has been focused on some main clinical and surgical aspects.

The clinical bottom line is that both types of cardioplegia resulted in overall similar short-term mortality, rate of postoperative complications, and release of myocardial enzymes.

Limited to the results obtained in our study, based on individual center experience,

in favor of warm blood cardioplegia we found a significantly lower need for PO blood unit transfusions, likely related to the lower degree of hemodilution determined by its use in comparison with the crystalloid cardioplegic so- 
lution [27]. In fact, in addition to the hemodilution of the extracorporeal circulation, there was also the hemodilution caused by the administration of the non-blood crystalloid solution, the infusion of which, based on the patient's weight, ranged between 1.2 and 1.6 liters on average, even reaching 1.8-2.0 liters per patient. Furthermore, confirming that the greatest need for blood transfusion was likely to be related to the hemodilution, there is the fact that the mean blood loss from thoracic drainages at 24 hours and the incidence of surgical re-exploration for bleeding were similar in the two study groups.

On the other hand, in favor of St. Thomas cardioplegia, considering that the re-dosing interval was 25-30 minutes $[3,28,29]$, with the same mean number of doses per patient compared with warm cardioplegia, it was possible to perform a greater number of distal coronary anastomoses per patient, which, as expected, required longer cardiopulmonary and aortic cross-clamp times.

An important aspect to underline was that the use of cold crystalloid cardioplegia in comparison with warm cardioplegia was associated with better myocardial protection, especially at the end of cardiopulmonary bypass. In fact, although the PO major outcomes and the more pronounced myocardial damage expressed as CK-MB ratio $>10 \%$ were found to be similar, the incidence of a more contained myocardial damage expressed by the CK-MB ratio $>5 \%$ was significantly lower in the ST group at time 0 . The fact that the crystalloid cardioplegia, even with its topical cooling effect of the myocardium, may have had a better protective effect is witnessed on the one hand by the fact that in the ST group a higher average number of grafts per patient was performed with consequent greater extracorporeal circulation and aortic clamping times, and on the other hand that in the multivariate analysis the length of these times was not predictive of a greater CK-MB release $>10 \%$ and $5 \%$.

From a technical-surgical point of view, the use of crystalloid cardioplegia may offer some advantage by allowing a longer time available for the packaging of distal coronary artery anastomoses and an operating bloodless field at the site of the anastomosis. However, if the surgeons prefer the warm cardioplegia, they should pay more attention to the interval time of administration, a shorter time of repetition of the dose being required to achieve effective myocardial protection [1, 18, 20, 28-30]. In fact, several studies performed on the use of warm blood cardioplegia have suggested the importance of the re-dosing interval [28-31]. In the study conducted at three cardiac surgical centers on 720 CABG patients, the authors concluded that antegrade warm cardioplegia was a valuable alternative to antegrade cold blood cardioplegia when the time off cardioplegia remained at 13 minutes [29, 31]. In another study in two groups of 250 elective CABG patients with the use of warm or cold blood cardioplegia, the authors observed better myocardial protection, i.e., CK-MB peak concentration (38 U/l vs. $51 \mathrm{U} / \mathrm{l}$ ) and percent of total CK (6.2\% vs. 8.2\%) in the warm cardioplegia group with a re-dosing interval of
15 minutes [32]. In accordance with the above-mentioned studies, we found a significantly lower rate of PO CK-MB ratio > 5\% (36\% vs. $59 \%$ at time 0 , and $13 \%$ vs. $18 \%$ PO 24 hours) when the re-dosing of the warm blood cardioplegia was done within 18 minutes in comparison with the longer 20-25 minutes interval.

There are several limitations of the study. First, although the population in question regarded isolated coronary artery surgery, it was a retrospective and observational analysis, not randomized. Secondly, although we excluded patients preoperatively affected by evolving myocardial infarction and subjected to coronary endarterectomy in which a much higher postoperative cardiac enzymatic increase could be expected due to the greater severity of coronary heart disease, we did not evaluate the potential impact of the Syntax Score on the intraoperative efficacy of both types of cardioplegic solutions on the myocardial protection. Finally, we compared only two types of cardioplegia, intermittently and antegrade administered, and the choice to administer one type of cardioplegia with respect to the other was mainly based on the choice of the surgeon, based on his personal experience.

\section{Conclusions}

In patients undergoing CABG we observed that early results were not affected by the use of two different types of cardioplegia. Both strategies appear to allow an equivalent and a satisfactory method for myocardial protection during the period of cardiac arrest.

Limited to the sample of patients and the experience of a single center, as compared with warm blood cardioplegia, cold crystalloid cardioplegia, with a similar mean number of doses per patient, allows a greater number of coronary anastomoses to be tolerated with longer times of aortic cross-clamp and cardiopulmonary bypass, and it is associated at the end of surgery with better protection at the CK-MB ratio level. As expected, the greater hemodilution that can occur with the use of this solution may require the need for greater blood transfusion in the postoperative period.

Warm blood cardioplegia allows better protection when it is administered with a shorter re-dosing interval, i.e., within 18 minutes versus 20-25 minutes.

Therefore, in view of the equivalence of the clinical results, the choice of one type of cardioplegia with respect to the other remains at the discretion of the surgeon.

\section{Disclosure}

The authors report no conflict of interest.

\section{References}

1. Buckberg GD, Athanasuleas CL. Cardioplegia: solution or strategies? Eur J Cardiothorac Surg 2016; 50: 787-791.

2. Flack JE, Cook JR, May SJ, Lemeshow S, Engelman RM, Rousou JA, Deaton DW. Does cardioplegia type affect outcome and survival in patients with advanced left ventricular dysfunction? Results form the CABG Patch trial. Circulation 2000; 102 (Suppl): III84-9. 
3. Barner HB. Blood cardioplegia: a review and comparison with crystalloid cardioplegia. Ann Thorac Surg 1991; 52: 1354-1367.

4. Ghazy T, Allham O, Ouda A, Kappert U, Matschke K. Is repeated administration of blood-cardioplegia really necessary? Interact Cardiovasc Thorac Surg 2009; 8: 517-523.

5. Comentale G, Giordano R, Palma G. Comparison of the different cardioplegic strategies in cardiac valves surgery: who wins the "arm-wrestling"? J Thorac Dis 2018; 10: 714-717.

6. Li Y, Lin H, Zhao Y, Li Z, Liu D, Wu X, Ji B, Gao B. Del Nido cardioplegia for myocardial protection in adult cardiac surgery: a systematic review and metaanalysis. ASAIO J 2018; 64: 360-367.

7. Nardi P, Pisano C, Bertoldo F, Ruvolo G. New insights on the use of del Nido cardioplegia in the adult cardiac surgery. J Thorac Dis 2018; 10 (Suppl 26): S3233-S3236.

8. Elvenes OP, Korvald C, Myklebust R, Sørlie D. Warm retrograde blood cardioplegia saves more ischemic myocardium but may cause a functional impairment compared to cold crystalloid. Eur J Cardiothorac Surg 2002; 22: 402-409.

9. Jacquet LM, Noirhomme PH, Van Dyck MJ, El Khoury GA, Matta AJ, Goenen MJ, Dion RA. Randomized trial of intermittent antegrade warm blood versus cold crystalloid cardioplegia. Ann Thorac Surg 1999; 67: 471-477.

10. Follette DM, Steed DL, Foglia RP, Fey KH, Buckberg GD. Reduction on postischemic myocardial damage by maintaining arrest during initial reperfusion. Surg Forum 1977; 28: 281-283.

11. The Warm Heart Investigators. Randomized trial of normothermic versus hypothermic coronary artery bypass surgery. Lancet 1994; 343: 559-563.

12. Ibrahim MF, Venn GE, Young CP, Chambers DJ. A clinical comparative study between crystalloid and blood-based St Thomas' hospital cardioplegic solution. Eur J Cardiothorac Surg 1999; 15: 75-83.

13. Edelman JJ, Seco M, Dunne B, Matzelle SJ, Murphy M, Joshi P5, Yan TD, Wilson MK, Bannon PG, Vallely MP, Passage J. Custodiol for myocardial and preservation: a systematic review. Ann Cardiothorac Surg 2013; 2: 717-728.

14. Fan $Y$, Zhang A, Xiao Y, Weng Y, Hetzer R. Warm versus cold cardioplegia for heart surgery: a meta-analysis. Eur J Cardiothorac Surg 2010; 37: 912-919.

15. Guru V, Omura J, Alghamdi AA, Weisel R, Fremes SE. Is blood superior to crystalloid cardioplegia? A meta-analysis of randomized clinical trials. Circulation 2006; 114 (Suppl): 1331-1338.

16. Abah U, Roberts PG, Ishaq M, De Silva R. Is cold or warm cardioplegia superior for myocardial protection? Interact Cardiovasc Thorac Surg 2012; 14: 848-855.

17. Zeng J, He W, Qu Z, Tang Y, Zhou Q, Zhang B. Cold blood versus crystalloid cardioplegia for myocardial protection in adult cardiac surgery: a metaanalysis of randomized controlled studies. J Cardiothorac Vasc Anesth 2014; 28: 674-681.

18. Fedosova M, Kimose HH, Greisen JR, Fast P, Gissel MS, Jakobsen CJ. Blood cardioplegia benefits only patients with a long cross-clamp time. Perfusion 2019; 34: 42-49.
19. Kuhn EW, Liakopoulos O, Slottosch I, Deppe AC, Choi YH, Madershahian N, Wahlers TCW. Buckberg versus Calafiore cardioplegia in patients with acute coronary syndromes. Thorac Cardiovasc Surg 2018; 66: 457-463.

20. Ulugol H, Aksu U, Kocyigit M, Kilercik M, Karduz G, Okten M, Toraman F. Comparative effects of blood and crystalloid cardioplegia on cellular injury and oxidative stress in cardiovascular surgery. Ann Thorac Cardiovasc Surg 2019; 25: 10-17.

21. de Jonge M, van Boxtel AG, Soliman Hamad MA, Mokhles MM, Bramer S, Osnabrugge RL, van Straten AH, Berreklouw E. Intermittent warm blood cardioplegia versus cold crystalloid cardioplegia for myocardial protection: a propensity score-matched analysis of 12-year single-center experience. Perfusion 2015; 30: 243-249.

22. Guajardo Salinas GE, Nutt R, Rodriguez-Araujo G. Del Nido cardioplegia in low risk adults undergoing first time coronary artery bypass surgery. Perfusion 2017; 32: 68-73.

23. Yerebakan H, Sorabella RA, Najjar M, Castillero E, Mongero L, Beck J, Hossain M, Takayama H, Williams MR, Naka Y, Argenziano M, Bacha E, Smith CR, Del Nido cardioplegia can be safely administered in high-risk coronary artery bypass grafting surgery after acute myocardial infarction: a propensity matched comparison. J Cardiothorac Surg 2014; 9: 141.

24. Ucak HA, Uncu H. Comparison of del Nido and intermittent warm blood cardioplegia in coronary artery bypass grafting Surgery. Ann Thorac Cardiovasc Surg 2019; 25: 39-45.

25. Li Y, Lin H, Zhao Y, Li Z, Liu D, Wu X, Ji B, Gao B. Del Nido cardioplegia for myocardial protection in adult cardiac surgery: a systematic review and metaanalysis. ASAIO 2018; 64: 360-367.

26. Sanetra K, Pawlak I, Cisowski M. Del Nido cardioplegia - what is the current evidence? Kardiochir Torakochirur Pol 2018; 15: 114-118.

27. Gunday M, Bingol H. Is crystalloid cardioplegia a strong predictor of intraoperative hemodilution? J Cardiothorac Surg 2014; 9: 23.

28. Hendry PJ, Masters RG, Haspect A. Is there a place for crystalloid cardioplegia in 1990s? Ann Thorac Surg 1994; 58: 1690-1694.

29. Durandy YD. Is there a rationale for short cardioplegia re-dosing intervals? World J Cardiol 2015; 7: 658-664.

30. Warner KG, Sheahan MG, Arebi SM, Banerjee A, Deiss-Shrem JM, Khabbaz KR. Proper timing of blood cardioplegia in infant lambs: superiority of a multiple-dose regimen. Ann Thorac Surg 2001; 71: 872-876.

31. Lichtenstein SV, Naylor CD, Feindel CM, Sykora K, Abel JG, Slutsky AS, Mazer CD, Christakis GT, Goldman BS, Fremes SE. Intermittent warm blood cardioplegia. Warm Heart Investigators. Circulation 1995; 92 (Suppl): ॥341-॥346.

32. Calafiore AM, Teodori G, Mezzetti A, Bosco G, Verna AM, Di Giammarco G, Lapenna D. Intermittent antegrade warm blood cardioplegia. Ann Thorac Surg 1995; 59: 398-402. 